\title{
CYTOTOXICITY STUDY OF FERULA HERMONIS BOISS
}

Abdurrahim A. Elouzi ${ }^{1,3^{*}}$, Abdurazag A. Auzi ${ }^{2}$, Mazen El-Hammadi ${ }^{3,4}$ and Alexander I. Gray ${ }^{5}$

${ }^{1}$ Department of Pharmaceutical Sciences, Faculty of Pharmacy, Elfateh University, Tripoli, Libya

${ }^{2}$ Department of Pharmacognosy, Faculty of Pharmacy, Elfateh University, Tripoli, Libya

${ }^{3}$ Department of Pharmaceutical Sciences, Faculty of Pharmacy, Damascus University, Syria

${ }^{4}$ Department of Medical Oncology, Cancer Research Center UK Beatson Laboratory, University of Glasgow G61 1BD

${ }^{5}$ Department of Pharmacognosy, University of Strathclyde, Glasgow G4 ONR, UK

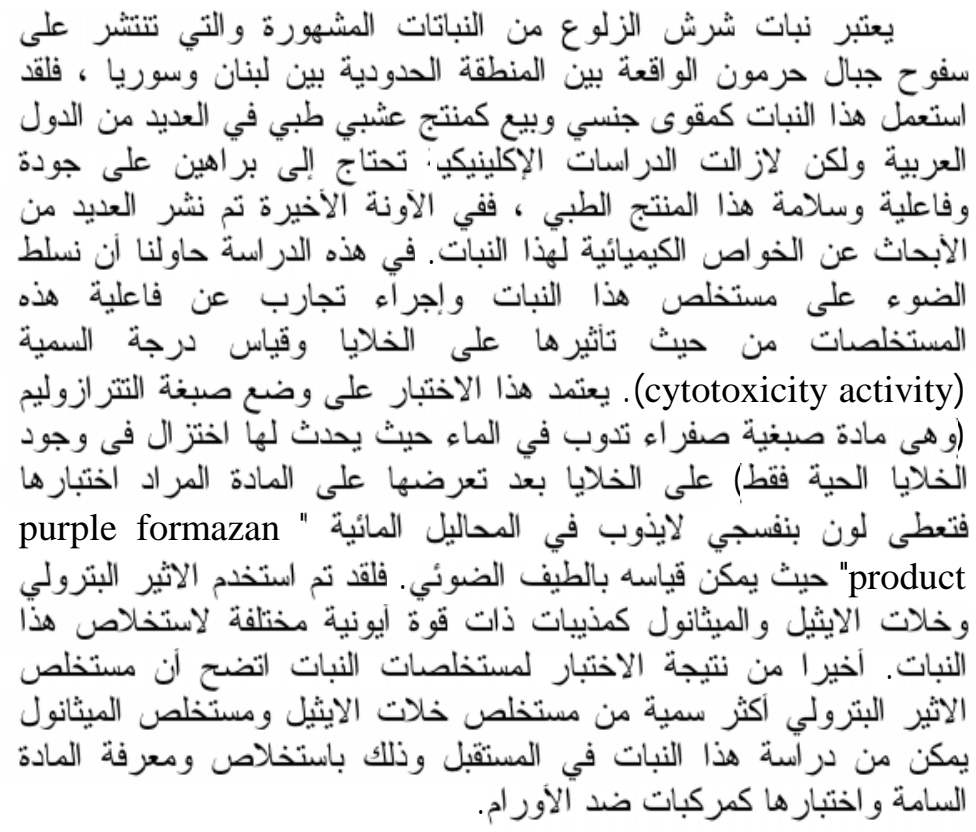

Ferula hermonis Boiss (Apiaceae) is known in the Midleast as 'zallouh'. In the last decade, scientists paid attention to study chemistry and biological activity of the plant. In this study Ferula

Received in 20/9/2008, Received in revised form in 17/11/2008 \& Accepted in 18/11/2008

*Corresponding author e-mail address: abdurahim68@hotmail.com 
hermonis were collected and evaluated for cytotoxic activity. The plant was extracted using different polarity solvents: petroleum ether, ethyl acetate and methanol. The cytotoxic effect of the extracts was examined in-vitro on human cell line (stomach cancer cell line, SCL-40). The assay was based on incubation of tetrazolium dye (MTT; a yellow water-soluble tetrazolium dye that is reduced by live, but not dead cells) with the cells that preincubated with a tested substance. A purple formazan product that produced can be determined spectrophotometrically.

The result confirmed that the SCL-40 cells were much more sensitive to the petroleum extract than other extracts, which showed the prominent cytotoxicity. The plant showed pronounced cytotoxic activity will be further evaluated for the possible isolation of active antitumour compounds.

\section{INTRODUCTION}

Ferula hermonis is well known for its traditional use in impotence for both men and women. In the South of Lebanon $F$. hermonis is known as Shilsh-el-zallouh which means "hairy root" whilst in the north of Lebanon it is called Hashishat-al-kattira, meaning "herb of abundance" . Ferula hermonis has recently received much attention due to its commercial value as an aphrodisiac, and as an herbal alternative to Viagra $^{2-5}$. Auzi and co workers ${ }^{4}$ have recently reported 17 sesquiterpene compounds from the seed of $F$. hermonis. While Ferula may achieve the same positive results as Viagra, Unfortunately, the plant doesn't come with the drugs long list of harmful side effects that has been reported which include facial flushing, upset stomachs, headaches, heart complications, urinary tract infections, and abnormal vision ${ }^{2}$.
Despite this fact, the plant is still sold in many herbal shops. In the current study the possible cytotoxicity of the plant was evaluated.

\section{MATERIALS AND METHODS}

\section{Materials}

Solvents; Petroleum ether 40$60^{\circ} \mathrm{C}$, ethyl acetate (EtOAc), methanol $(\mathrm{MeOH}), \quad$ and dimethylsulphoxide (DMSO) were obtained from Sigma Company.

Stomach cancer cell line (SCL40). 3-(4,5-dimethylthiazole-2-yl)2,5-diphenyltetrazolium bromide (MTT, Molecular Probes Europe BV, The Netherlands), RPMI-1640 (Roswell Park Memorial Institute), $10 \%$ foetal calf serum (Sigma-Aldrich Co,UK), $1 \%$ penicillin/streptomycin and 1\% L-glutamine (Sigma-Aldrich Co,UK), silica gel GF245 (SigmaAldrich Co,UK), 96 well microtiter plate (Tissue Culture) and Light microscope. 


\section{Plant material}

The plant was collected from Hermon Mountain Lebanon and identified by the herbarium of Botany Department Faculty of Sciences, Elfateh University, Tripoli-Libya. A voucher specimen (FH2002) was deposited in the herbarium.

\section{Extraction of plant material}

$350 \mathrm{gm}$ of the powdered roots of Ferula plant was macerated successively in petroleum ether 40$60^{\circ} \mathrm{C}$, EtOAc and methanol. The extracts were concentrated under reduced pressure using a rotary evaporator to get rid of the solvents. The amount of extracts was $20 \mathrm{~g}$ (oil), $12 \mathrm{~g}$ and $18 \mathrm{~g}$ for petroleum ether, EtOAc and methanol, respectively.

\section{In vitro acute cytotoxicity assay}

Each extract was dissolved in 0.2 $\mathrm{ml}$ solvent DMSO for the in vitro for cytotoxicity evaluation against stomach cancer cell line (SCL-40) ${ }^{6}$.

Cells were cultured in RPMI1640, supplemented with heat inactivated $10 \%$ foetal calf serum, $1 \%$ penicillin/streptomycin and $1 \% \mathrm{~L}$ glutamine incubated at $37^{\circ} \mathrm{C}$ and $5 \%$ $\mathrm{CO}_{2}$ at aseptic condition. The cytotoxicity was assessed by the measurement of the $\mathrm{LD}_{50}$ value in a standard MTT.

The MTT assay was carried out as follows; the cells were seeded at a concentration of 1-2 × $10^{5}$ cells/well of a 96 well microtiter plate. Each concentration was replicated 6 times. The cells were treated with two-fold serial dilution of extracts, medium alone to which no sample was added (positive control and produced 100\% viability), and DMSO alone that was used as a negative control and produce $0 \%$ viability.

Samples were dissolved in $0.2 \mathrm{ml}$ DMSO and made up to $1 \mathrm{ml}$ with the medium. The sample solution was filtered and sterilized before being added to the cells. $100 \quad 1$ of cells in medium was pipetted into each well, 901 of medium was added and the 101 of sample added accordingly.

After $24 \mathrm{hrs,}$ the plates were viewed under the microscope to record visual observations and to check for any contamination. The medium was then removed gently and then $150 \quad 1$ of fresh medium and 50 1 of sterile solution MTT $(1 \mathrm{mg} / \mathrm{ml}$ medium) were added in each well.

The plates were incubated for 3-4 hrs; the well contents were carefully removed. At this stage the blue formazan crystal were visible at the bottom of wells, which had contained live cells. $1001 \mathrm{DMSO}$ was added to dissolve any crystals present. The plate was shaken on a shaker for 5 minutes and absorbance was determined at $570 \mathrm{~nm}$.

Solvent and medium were also examined as control. The percent suppression in cell viability for the test sample was determined by comparing the absorbance of the test sample with the mean control value ${ }^{7}$. The mean suppression and standard errors were calculated (Figs. 1\&2). The graphs were used to determine the $\mathrm{LD}_{50}$, which is the concentration at which $50 \%$ cell death suppression occurred. 


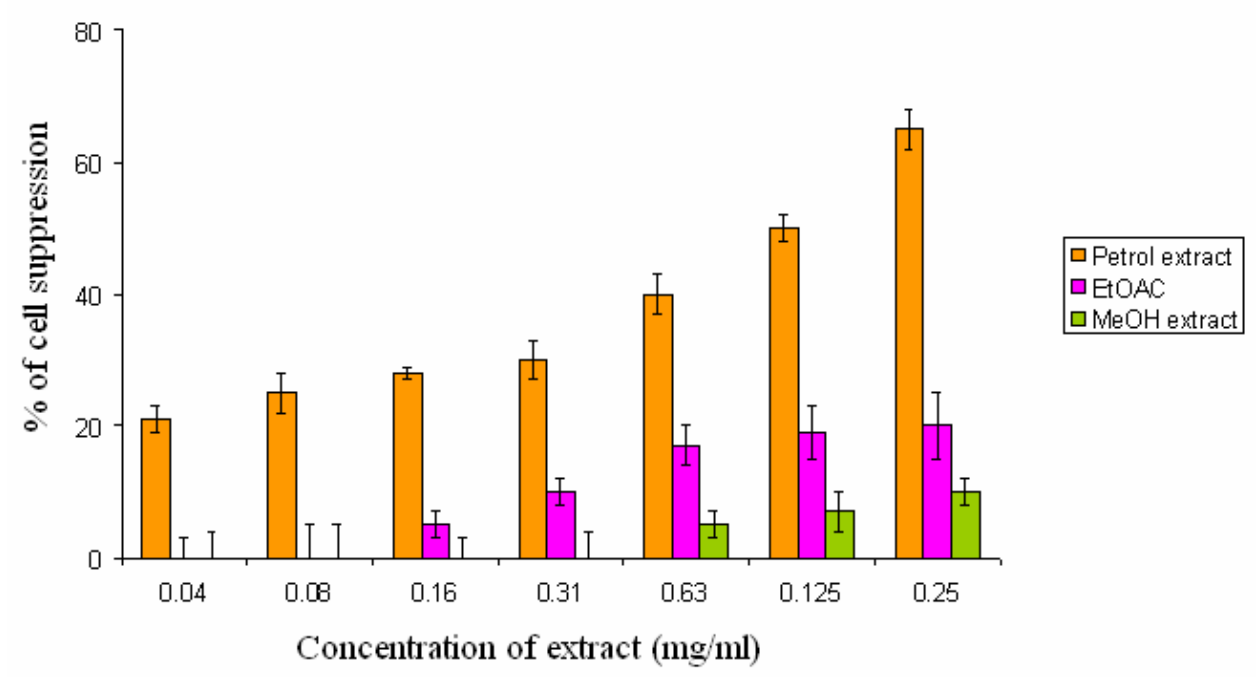

Fig. 1: The effect of extract concentration on the $\%$ of cell suppression.

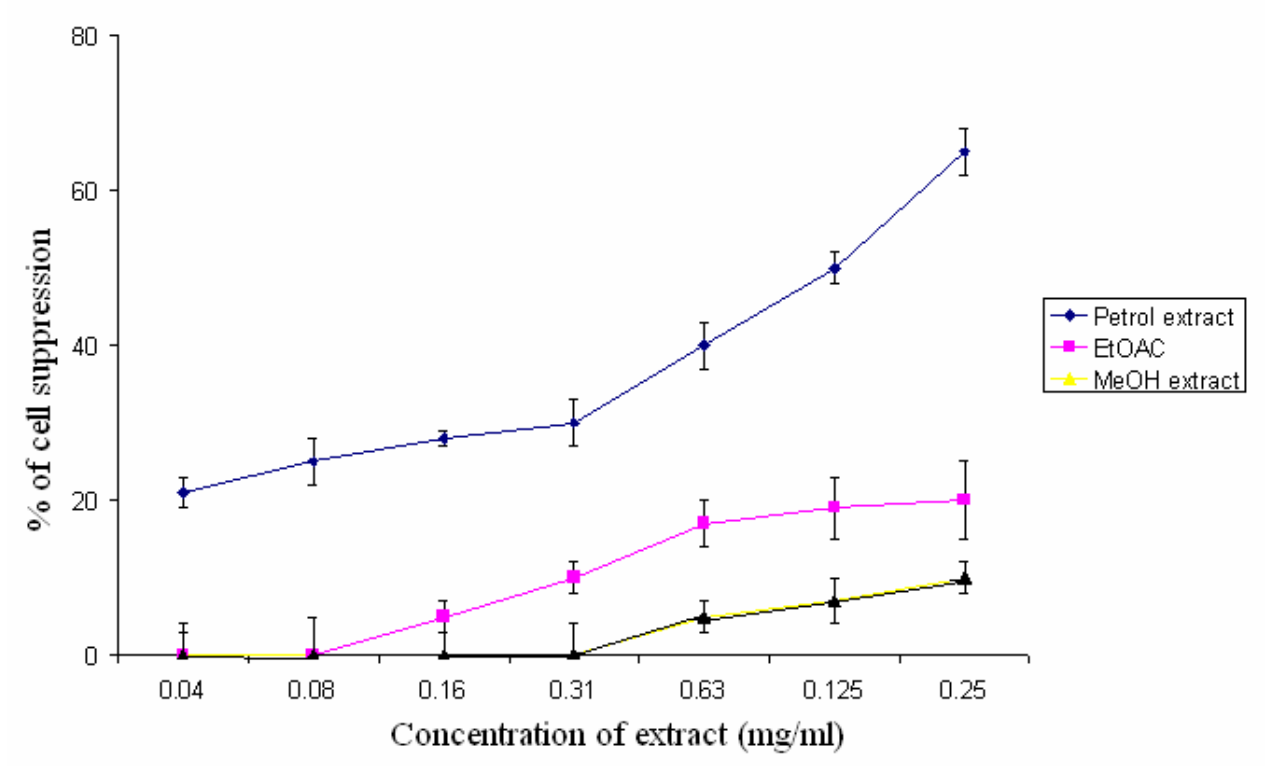

Fig. 2: $\mathrm{IC}_{50}$ values of various Ferula hermonis extracts against SCL-40. 


\section{RESULTS AND DISCUSSION}

The data in Table 1 showed that out of the three extracts, the petroleum extract at a concentration of $0.125 \mathrm{mg} / \mathrm{ml}$ causes $50 \%$ cell death suppression and was most cytotoxic. The EtOAc and methanol extracts at the concentration of 0.125 displayed cell deaths of $19 \%$ and $7 \%$ respectively (Figs. 1\&2). Recent studies have demonstrated that the compounds commonly found in extract of Ferula hermonis with petroleum ether are sesquiterpenes ${ }^{4}$, therefore, It can be assumed that the sesquiterpenes might be responsible for cytotoxicity of Ferula hermonis. Further study is underway to isolate and examine pure active major compounds for cytotoxic effect and other pharmacological activity ${ }^{8}$.

Table 1: The $\%$ of the cell suppression by Ferula hermonis extracts against SCL-40 cells.

\begin{tabular}{|c|c|c|c|}
\hline \multirow{2}{*}{$\begin{array}{l}\text { Concentrat- } \\
\text { ion of the } \\
\text { extract } \\
(\mathrm{mg} / \mathrm{ml})\end{array}$} & \multicolumn{3}{|c|}{$\%$ of cell suppression } \\
\hline & $\begin{array}{c}\text { Petroleum } \\
\text { extract }\end{array}$ & $\begin{array}{l}\text { EtOAc } \\
\text { extract }\end{array}$ & $\begin{array}{l}\mathrm{MeOH} \\
\text { extract }\end{array}$ \\
\hline 0.04 & 21 & ND & ND \\
\hline 0.08 & 25 & ND & ND \\
\hline 0.16 & 28 & 5 & ND \\
\hline 0.31 & 30 & 10 & ND \\
\hline 0.63 & 40 & 17 & 5 \\
\hline 0.125 & 50 & 19 & 7 \\
\hline
\end{tabular}

$\mathrm{ND}=$ Non detected in the used concentrations

\section{Conclusion}

The present study supports the previous report for toxicity of Ferula hermonis $^{2}$. Therefore, the use of $F$. hermonis as an herbal medicine should be under strict control to avoid any health complication.

\section{Acknowledgments}

The Authors like to thank herbarium of Botany Department Faculty of Sciences, Elfateh University for systematic identification of plant sample.

\section{REFERENCES}

1- T. S. El-Taher, K. Z. Matalka, H. A. Taha, et al., Journal of Impotence, 13, 247 (2001).

2- Z. Paola, Z. Manuela, et al., Physiology \& Behavior., 86 (2005).

3- I. I. Hamdan and F. U. Afifi, Journal of Ethnopharmacology, 93 (2004).

4- A. A. Auzi, I. A. Gray, M. M. Salem, A. A. Badwan and S. D. Sarker, Journal of Asian Natural Products Research., 10, 701 (2008).

5- Tsunetake Motai and Susumu Kitanaka, Journal of Natural Medicine, 60 (2005).

6- R. I. Freshney, "Culture of Animal Cells; A manual of Basic Technique", $3^{\text {rd }}$ Edn., New York, Wiley- Liss. XXIV, 1994, p. 486.

7- A. A. Elouzi, I. F. Uchegbu, et al., Proceed $30^{\text {th }}$ Ann. Meet. Exposit. Control. Rel. Soc., 30, Abstract number 635 (2003).

8- A. Elgaroshy, "Screening for Bioactive Compounds from Ferula hermonis". Current MSc Project in Phytochemistry, Pharmacognosy Department., Faculty of Pharmacy, Tripoli, Libya (2007). 